\title{
Questioning Bangladesh's Microcredit
}

\author{
Rafiqul Islam Molla \\ Specialist in Economics \\ Faculty of Business and Law \\ Multimeida University \\ Melaka Campus, Melaka, Malaysia \\ Tel: +60 6252 3092, Fax: +60 62318869 \\ E-mail: rimolla@gmail.com \\ M. Mahmudul Alam \\ Deputy Manager \\ Customer Relationship Management (CRM) \\ Marketing Division \\ Grameenphone Ltd. \\ Dhaka, Bangladesh \\ Mobile: +88 01711503782 \\ Email: rony000@gmail.com \\ Dr. Abu N.M. Wahid \\ Editor, The Journal of Developing Areas \\ Professor \\ Department of Economics and Finance \\ Tennessee State University \\ $33010^{\text {th }}$ Ave. North \\ Nashville, TN 37203-3401, USA \\ Tel: 615-963-7149, Fax: 615-963-7139 \\ Email: awahid@tnstate.edu
}

\section{Citation Reference:}

Molla, R. I., Alam, M.M., and Wahid, A.N.M. 2008. Questioning Bangladesh's Microcredit, Challenge: the Magazine of Economic Affairs, Vol. 51(6), pp.113-121. vailable at < http://www.tandfonline.com/doi/abs/10.2753/0577-5132510608>, DOI: $10.2753 / 0577-5132510608$.

This is a pre-publication copy.

The published article is copyrighted by the publisher of the journal. 


\title{
Questioning Bangladesh's Microcredit
}

\author{
Rafiqul Islam Molla, M. Mahmudul Alam, Abu N.M. Wahid
}

\begin{abstract}
The microcredit (MC) program of Bangladesh has been a well-known success story for generation of self-employment, and poverty alleviation. Variants of this MC model are being implemented in more than 60 different countries of the world. It has become almost a universal antidote for poverty especially from 2006 when Professor Muhammad Yunusthe founder of the Grameen Bank (GB) and the bank itself shared the Nobel peace prize. Although the GB is the pioneer of MC program in Bangladesh, there are many other nongovernmental organizations (NGO)s that offer the same program in Bangladesh in different forms and names. The providers of MCs claim that the overwhelming majority of the borrowers are using the loan funds profitably for productive purposes, repaying the loans and interest regularly, and thus improving their socio-economic conditions steadily. The findings of the present study are somewhat contrary and disturbing to the claim of the MC programs. This study finds that a bulk of the MC is borrowed for non productive purposes. About one quarter of the borrowers use the credit exclusively for consumption and debt repayment purposes. Nearly half of them use the credits entirely for investment purposes. For all, the return on investment is very meager. About two-third of the borrowers, on average have an impressive $83 \%$ net return on investment available for payment of interest and dividend in addition to the principal. But in case of as high as one third of them, average return on investment is not enough even to cover the most minimum or tolerance level of wages for family labors, let alone paying any interest and making any profit after keeping aside the principal.
\end{abstract}

Keywords: Microlending, microcredit, microenterprise, implicit cost of labor, small business

\section{Introduction}

When Muhammad Yunus was a professor of economics at Chittagong University of Bangladesh in the early 1970s, he witnessed the miserable plight of the rural poor people of Bangladesh with his own eyes. On his way to the university campus, in a nearby village (named Jobra), almost regularly he watched the villagers especially women folks engaged in economic and business activities. He found them very hard working and yet their condition remained unchanged for years. He took interest in their affairs and discovered that those small entrepreneurs were running their businesses with funds borrowed from local moneylenders at an exorbitantly high rate of interest -as high as over $120 \%$. That was one of the main reasons the poor people were trapped in the vicious cycle of poverty, debt, low income, and poverty. He approached some local banks to get small loans for these entrepreneurs at market rate of interest. The banks refused to deal with them as they were too risky having no collateral.

In order to make loans available to these microentrepreneurs at an affordable and reasonable rate of interest, Muhammad Yunus founded the Grameen Bank (GB) in 1976 as a pilot project with some borrowed capital from the Agricultural Bank of Bangladesh. 
The GB is the pioneer of microcredit ${ }^{\mathrm{i}}$ (MC) in Bangladesh. However, there are nearly 700 other non-governmental organizations (NGO)s of various sizes who provide MC to millions of borrowers in Bangladesh. At present, in Bangladesh, there are about 9 million ${ }^{\text {ii }}$ households who are benefiting from this program being offered by the GB and other NGOs.

\section{A Critique of the Microcredit Program and Our Pilot Project}

The interest rate being charged by the GB and other NGOs in Bangladesh is very high -as high as $25-65 \%$ (Third Sector, March 2004). Thus the providers of microcredits are under harsh criticisms from, economists, development activists, and politicians alike. In 2005, Saifur Rahman-the then Finance Minister of Bangladesh, blasted that if the microcredit lending NGOs continue to charge such abnormally high interest rate from the poor borrowers, the lots of the poor could not be improved even in centuries. According to him, as the MC providers get a large bulk of its fund from the government and international agencies at only 4-5\% interest rate, they should not charge the poor borrowers more than 8-9\% interest (The Independent, November 2005). The NGOs however, argue that microcredit delivery and supervision cost is very high; and as such, a high interest rate charge is required to cover the high costs. They also claim that the high rate of growth of the borrowers at this high rate of interest indicates that the microcredit is highly productive and profitable for the borrowers making them capable of easily repaying the loan and interest.

The Consultative Group to Assist the Poor (CGAP) observes that the poor borrowers face only a very low-return economic opportunities, as a result, there is no reason to believe that they can afford to pay the high interest rates (Todaro, 2006). An empirical study suggests that the microcredit programs and institutions have in fact generated a positive but marginal change in the incomes of beneficiaries. Now that the Grameen Bank and its founder Muhammad Yunus gets the Noble peace prize for pioneering microcredit as a tool for fighting poverty, many serious empirical studies are required in terms of delivery cost and borrowers' benefits for proper evaluation of the claimed effectiveness of microcredit program as a strategy for poverty alleviation. As an attempt to reevaluate the claim of the MC providers, we have undertaken the present pilot study in Dagon Bhuyan Upazilla under the district of Feni. This pilot study chooses a sample of 25 selected borrowers from 3 selected villages. Working convenience of the researchers, cooperation of the borrowers, and coverage of borrowers of different sizes and economic activities guides the selection of sample villages and borrowers. It therefore suffers from all the usual methodological limitations of a pilot study - location specific and too small sample size making it unable to accommodate more variations that prevail in the country. It was carried out in the year 2005-06.

In analyzing the benefits of the borrowers and the effectiveness of the microcredit programs, the NGOs take resort to calculating accounting profit of borrowers' business enterprises and ignore implicit costs under the plea that the opportunity cost of labor is zero or near zero in these countries. This plea is certainly not tenable and if insisted, it will amount to going back to the concept of distressed selling of labor (much like slavery) in the medieval age making it self defeating as a strategy for poverty alleviation. Moreover, under the circumstances of high rate of unemployment in the country, many members of the rural poor households may have to remain virtually without any productive employment during a certain part of the year, but, of course, not the whole year. During 
the sowing and harvesting seasons, there can be even shortages of labor resulting in very high wages. In this study, therefore, we have used the concept of economic profit in benefit analysis of the borrowers to determine the maximum interest rate that the borrowers can afford to pay and still remain motivated to borrowing for carrying on with the entrepreneurial operations earning normal profits (which is equal to at least the implicit costs of labor). Keeping in mind the periodic fluctuation of employment and wages and other social circumstances in rural areas, a very conservative wage rate of Tk 5 for male and Tk 3 for female per hour has been used in calculating the imputed cost of economic operations of the microcredit borrowers.

\section{Use of the Borrowed Funds}

One of the key and traditional features of microcredit is that the small borrowers usually borrow not necessarily for investment purposes but most often for consumption (including marriage of children and socio-religious rituals) and debt repayment purposes. In the pilot project survey, we find that only $48 \%$ of the borrowers (12 out of 25 sample borrowers) use the credit fund entirely for investment purposes in productive economic activities. Six of them have not made any investment at all. They have used the entire borrowed fund for consumption purposes. Thirteen of them have used the borrowed funds for both consumption and investment purposes. Thus 19 of them have used the borrowed funds for investment purposes either fully or partially. Twelve of them have invested their past savings in addition to the borrowed capital at the beginning of the project period. Sixteen of them have added more funds to the borrowed capital from their own later on during the project period 2004-05. For the 19 who have made investments, the average size of their investments from borrowed funds is Taka 4,806. Average size of their own investment both initially and later during the project period is Taka 9,105. Thus, the total average investment is Taka 13,911. Average gross profit is Taka 27,084. Average implicit cost of labor for these 19 is Taka 13,798. Thus the net profit available for the payment of interest and dividend is Taka 13,286. The average picture appears to be quite rosy. However, if we look at the individual situation, out of these 19, 6 of them have ended up with negative net profit.

Therefore the bulk of the microcredit borrowings are for non productive purposes without any scope and expectation of revenue generation for loan repayment; these are mostly for survival and meeting contingencies. Economic demand (economic costs) from these borrowers does not make any sense. It shows that the claim that microcrdit is a 'strictly supervised credit', is no longer valid; often credit money gets diverted to non-productive purposes leading borrowers in utterly distressed situation when the time comes for repayment. In that situation, loan is repeated just to keep the weekly installments going with tacit approval of the microcredit dispenser to show their repayment rates high to the outside world.

\section{Social Aspects of Microcredit Program in Bangladesh}

Selling labor in the open market is not a very prestigious thing in traditional rural culture in Bnagladesh. Therefore, many poor people despite their desperate economic condition do not want to work for others. They would rather like to work in their own farms and businesses even if these engagements are much less rewarding. Sometimes, they earn at or below subsistence level of income from self-employment opportunities. Taking this and other social dynamics into account, we use the least wages @ Tk 5 per hour for man and 
Tk 3 for woman in imputing the least wages for family labor used in the economic enterprise.

\section{Use of the Borrowed Funds and Gross Profit}

As per our survey results, the 19 enterprises are productive to generate surpluses barely enough to pay family labor wages at normal rate (Tk 10 per hour for male and Tk 6 for female) and left with nothing at all for payment of any interest for capital, not to speak of dividend for the household entrepreneurs. However, if family labor is paid wages only at a tolerance or below subsistence level (Tk 5 per hour for male and Tk 3 for female) a net worth or surplus of Tk 13,287 is available for paying interest and dividend. The surplus amounts to about $96 \%$ of capital invested. After paying interest for capital @ as high as 25\% (Tk. 3,478), an impressive amount of surplus Tk 10,433 is available even for paying dividend to households. But if we dispel the magic of the average, the real stories come out.

Survey findings also suggest that about 68\% (13 out of 19) of them on average are productive and able to generate surplus high enough even to pay family labor wages at normal rate and leave with a balance i.e. net worth amounting to $83 \%$ of the capital available for paying interest for capital and dividend for the household. On the other hand $32 \%$ (6 out of 19) of them are not able to generate surplus sufficient enough even to fully pay family labor wages at a tolerance or below subsistence level, talk less of paying any interest or dividend. For them, the average imputed tolerance level of family labor cost is Tk. 17,380 where as the surplus available is Tk 9,313 i.e. only just over half the most minimum level of wages for family labor. Therefore, on top of it, if any interest is paid for the credit capital, it will be at the expense of sacrifice of this meager wages of the family labor. In fact, this is the harsh reality and the core of the problems for a substantial number of micro economic enterprises operating in rural areas. In the absence of a built-in institutional provision for debt relief/exemption, this large group of microcredit borrowers is pushed to a vicious cycle of poverty, debt, and poverty with no scope for gaining freedom from the bondage of debt.

\section{Opportunities for those who Invest the Entire Borrowed Funds}

Borrowers who use their entire borrowed fund for investment, are relatively better-off. They generally borrow to add to their own funds for investment. They are relatively large investors. Their average total investment (Tk 18,125) is nearly 3 times larger than that of those who use only part of the borrowed funds for investment (Table 2). But their average net worth (Tk 11,421) is less than that of the smaller investors. Borrowers who rely heavily on borrowed funds for investment, are generally small investors. Where borrowed funds constitute $52-100 \%$ of total investment, the average total investment is Tk. 8,524, and where it is $16-22 \%$ the average total investment is Tk. 24,105 . However, it is not clear that large investors have necessarily large net worth. This tends to suggest that microcredit borrowers in rural areas are engaged in low-return economic activities; higher investment does not have much scope in the types of economic opportunities available to them. It, therefore, lends support to the observation of the CGAP, that bulk of the microcredit borrowers face only a very low-return economic opportunities.

\section{Prospects of Productive Self-employment from Microcredit}


Scholars and researches are in agreement that microcredit and micro economic enterprises cannot be taken as a growth strategy for economic development. However, rural development and for that matter rural small scale economic enterprises, and microcredit facilities are complementary features of any development strategy. Job creation for teeming millions of unskilled and semiskilled laborers is the bottom line for any development strategy in any labor abundant developing country. Therefore, any microcredit program has to be assessed based on its productivity in job creation (its role in promoting productive micro economic enterprises/self-employment). This social dimension of job creation (self-employment) is the most emphatic feature of microcredit program. The study also finds that in $37 \%$ cases (7 out of 19) borrowed funds constitute over $50 \%$ of their total investments. It is also revealed that on average each borrower, with an investment of $\mathrm{Tk} 13,911$, is able to create opportunities for 431 man-days of family labor ( minimum total wages for family labor divided by average of male and female wages per hour divided by 8 hours of work per day i.e. $[13798 \div(5+3) / 2] \div 8)$. It means, for each one thousand taka annual investment, there is a creation of opportunities for about $13,911 \div 431=31$ man-days of family labor. Therefore, it requires investment of around Tk 12,000 for creating self-employment for a person for a year.

For groups of large and small investors, job creation per thousand taka invested ranges from 23 to $44{ }^{\text {iii }}$ man-days of family labor. Therefore, there is no clear indication that higher investment, within limits, creates opportunities for higher number of selfemployments. This again suggests that higher investment has limited social and economic scopes in economic activities open to the microcredit borrowers in rural areas.

\section{Conclusions}

Microlending and microcredit have become integral parts of development strategy in almost all developing countries of the world. According to the findings of this study, the prospect of microcredit to enhance meaningful and productive self employment and real income of rural households is at best marginal. Any investment in the amount of less than Taka 12,000 is not adequate to create one productive full-time job for a year. The study reveals that if family labor is paid a most nominal or tolerance level of wages @ Tk 5 per hour for male and Tk 3 for female, the micro enterprises on average may have surpluses enough to pay the current high rate of interests charged by the Grameen Bank and other NGOs. This suggests that the exorbitantly high rate of interest charged by the loan providers, are in fact forcing the laborers to sell their labor at or below subsistence rate of wage. More importantly, for a significant percentage of borrowers (32\%) the gross profit is not sufficient to pay even the most nominal or tolerance level (below subsistence level) of wages for family labor, talk less of payment of interest and dividend. The microcredit providers in Bangladesh must find more socially equitable and justifiable way to address this issue. Otherwise, the very purpose of microcredit will eventually fail. The bulk of the millions borrowers will remain in the trap of poverty, debt, and poverty.

The findings of this pilot study is stunning and disturbing because they are clearly in contradiction to the claims of the microcredit providers in Bangladesh. However, one thing must be taken into cognizance seriously, that is the sample of this pilot project is too small. We cannot draw conclusion about millions, based on a sample of as small as 25 only. However, we firmly believe that it is worth reexamining the usual claims of the NGOs by undertaking more comprehensive research projects with larger samples in various parts of Bangladesh. 


\section{Endnotes}

${ }^{\mathrm{i}}$ Oxfam International defines microcredit as a variety of small scale financial services including savings, loans for emergencies, day-to-day living, and investment in productive activities.

${ }^{\text {ii }}$ Out of 9 million, nearly 6.7 million are exclusively GB clients.

iii $[16,959 \div(5+3) / 2] \div 8 \div 12.016=44 ; 17,825(5+3) / 2] \div 8 \div 24.105=23$; and $7525(5+3) / 2] \div 8 \div$ $8.524=28$.

\section{References}

Credit and Development Forum (2002), Microfinance Statistics, Vol.14, June.

Khan, M. F. (1988), "Production Organization and Employment Strategy in an Islamic Economy", in Molla, et. al. (ed), Frontiers and Mechanics of Islamic Economics, University of Sokoto, Nigeria

The Independent (2005), "Saifur Blasts NGOs For Fleecing The Poor", Nov.11, Dhaka.

Third Sector (2004), "Specialist - Abu Barakat's View about Microcredit Program that are Run by NGOs", March, pp.24, Dhaka.

Todaro, Michael P. and Smith, S. C. (2006). Economic Development, $9^{\text {th }}$ Edition, p753, Pearson and Addison-Wesley, London.

Yunus, Muhammad (2003), "What is Microcredit ?", Available at <http://www.grameeninfo.org/mcredit> 